Original article

\title{
Design and synthesis of bioactive adamantanaminoalcohols and adamantanamines
}

\author{
Grigoris Zoidis ${ }^{a}$, Nicolas Kolocouris ${ }^{\mathrm{a}, *}$, John M. Kelly ${ }^{\mathrm{b}}$, S. Radhika Prathalingam ${ }^{\mathrm{b}}$, Lieve Naesens ${ }^{\mathrm{c}}$, \\ Erik De Clercq $^{\mathrm{c}}$
}

${ }^{a}$ Faculty of Pharmacy, Department of Pharmaceutical Chemistry, University of Athens, Panepistimioupoli-Zografou, GR-15771 Athens, Greece

${ }^{\mathrm{b}}$ London School of Hygiene and Tropical Medicine, Department of Infectious and Tropical Diseases, Keppel Street, London WC1E 7HT, UK

${ }^{\mathrm{c}}$ Rega Institute, Department of Microbiology and Immunology, Katholieke Universiteit Leuven, Minderbroedersstraat 10, 3000 Leuven, Belgium

\section{A R T I C L E I N F O}

\section{Article history:}

Received 16 April 2010

Received in revised form

4 August 2010

Accepted 6 August 2010

Available online 12 August 2010

\section{Keywords:}

Adamantane aminoalcohols and diamines

Anti-influenza A virus agents

H3N2

Rimantadine

Trypanocidal activity

NMR

\begin{abstract}
A B S T R A C T
Adamantanamines 16, 18, 21, 24, 27, 28, 30, 32, 35, 36, 37, 40, 46 and 48 were synthesized and tested for anti-influenza A virus and trypanocidal activity. The stereoelectronic requirements for optimal antiviral and trypanocidal potency were investigated. The effect of introducing a hydroxyl group close to the amino group on this class of compounds was examined for the first time. Aminoalcohol 24 proved to be the most active of the compounds tested against influenza A virus, being 6-fold more active than amantadine, equipotent to rimantadine and 26-fold more potent than ribavirin. Aminoalcohols $\mathbf{3 6}$ and $\mathbf{3 7}$ were found to have considerable activity against bloodstream forms of the African trypanosome, Trypanosoma brucei, being almost 10 times more potent than rimantadine.
\end{abstract}

(c) 2010 Elsevier Masson SAS. All rights reserved.

\section{Introduction}

Influenza is a highly contagious infectious disease that affects millions of people every year. In the twentieth century, influenza caused more fatalities in Europe than any other infectious disease [1]. Current vaccines against influenza virus have limited effectiveness due to the rapid emergence of strains with mutated viral antigens. Thus, anti-influenza drugs are vital as a first line of defense. At present, two classes of antivirals are available: the neuraminidase inhibitors oseltamivir and zanamivir, and the M2 proton channel blockers amantadine and rimantadine [5].

The cumulative impact of recurrent annual epidemics is generally higher than that of the infrequent pandemics, although the extreme mortality of the H5N1 avian influenza virus is a serious reason for concern. This H5N1 virus originated in 1997 in Hong Kong and has since spread (through birds) to Southeast Asia and other countries, with occasional transmission to humans (almost 500 human cases, more than half of which were fatal). In 2003, another highly pathogenic avian influenza virus (H7N7 subtype)

\footnotetext{
* Corresponding author. Tel.: +30 210 7274809; fax: +30 2107274747

E-mail address: zoidis@pharm.uoa.gr (N. Kolocouris).
}

caused some 89 mild infections in the Netherlands and the death of a veterinarian, while in the same year H9N2 viruses were isolated from individuals with mild influenza [2]. The "swine flu" pandemic of 2009 was caused by a new H1N1 reassortant virus containing genome segments from human, avian and swine influenza viruses. Although the source of the outbreak in humans is still unknown, cases were first discovered in Mexico and the U.S.A. [3]. This new influenza pandemic prompted an unprecedented worldwide response consisting of containment measures, antiviral therapy and the development of a vaccine. The disease spectrum of this swine flu H1N1 virus is comparable to that of other human influenza viruses, although it remains unclear how the virus will evolve during the forthcoming months [4].

Amantadine (1; Fig. 1) was the first anti-influenza drug to be developed. At micromolar concentrations, amantadine inhibits the function of the M2 proton channel of influenza A virus that is involved in virus uncoating [6,7]. After endocytosis of the virions, the M2 proton channel mediates acidification of the viral interior, resulting in a conformational change of the viral hemagglutinin (to its fusogenic form) and dissociation of viral ribonucleoprotein from the matrix protein. In addition, the $\mathrm{M} 2$ protein has a role in virus maturation, since it regulates the $\mathrm{pH}$ in the trans-Golgi network to prevent premature conformational rearrangement of 


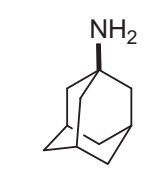

Amantadine

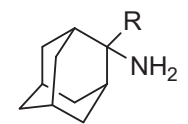

$8 \mathrm{R}=\mathrm{CH}_{3}$

$9 \mathrm{R}=\mathrm{C}_{2} \mathrm{H}_{5}$

$10 \mathrm{R}=n-\mathrm{C}_{3} \mathrm{H}_{7}$

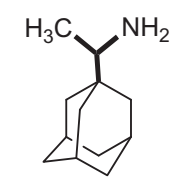

Rimantadine

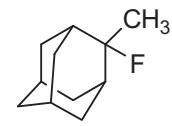

11<smiles>[R]C1C2CCC(CC2)C1([R3])C(C)N([R])C</smiles>

$1 \mathrm{R}_{1}, \mathrm{R}_{2}, \mathrm{R}_{3}=\mathrm{H}$

$2 \mathrm{R}_{1}, \mathrm{R}_{3}=\mathrm{H}, \mathrm{R}_{2}=\mathrm{CH}_{3}$

$3 \mathrm{R}_{1}, \mathrm{R}_{2}=\mathrm{CH}_{3}, \mathrm{R}_{3}=\mathrm{H}$

$4 \mathrm{R}_{1}, \mathrm{R}_{2}=\mathrm{H}, \mathrm{R}_{3}=\mathrm{CH}_{3}$

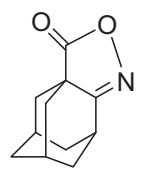

12<smiles>[R]C1(O)CC2CCC1CC2</smiles>

$5 \mathrm{R}=\mathrm{CH}_{3}$

$6 \mathrm{R}=\mathrm{C}_{2} \mathrm{H}_{5}$

$7 \mathrm{R}=n-\mathrm{C}_{3} \mathrm{H}_{7}$

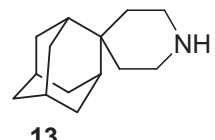

Fig. 1.

the hemagglutinin [6b]. During the past fourteen years, we have synthesized many potent aminoadamantane derivatives (Fig. 1) $[8,9]$. The protonated forms of these compounds are considered to block the tetrameric M2 ion channel pore [10], formed by its transmembrane domain M2TM [11], and hence, its proton transport function [12,13].

The desired property of new synthetic aminoadamantane derivatives is of course the effective inhibition of virus replication. The amantadine-M2 complex is probably stabilized through formation of hydrogen bonding between the drug's ammonium group and specific residues, probably His-37 or Ser-31, within the M2 acceptor site [10,12]. Here, we have examined the M2 binding properties of aminoadamantane derivatives that have a hydroxyl group at positions close to the amino group; the hydroxyl group could possibly participate as donor or acceptor in hydrogen bonding interaction with the receptor.

Among the many diseases that afflict humankind, those caused by protozoan parasites occupy an important place because of the large number of victims, the lack of efficient therapy, and their continuing spread. Tsetse fly-transmitted parasites of the Trypanosoma brucei species complex are the causative agents of Human African Trypanosomiasis (HAT), one of the world's great neglected diseases. The World Health Organization reported 55,000 deaths in 2002 out of 500,000 cases of sleeping sickness in sub-Saharan Africa [14]. Recently, the annual incidence has varied between 50,000 and 300,000 cases, with about 60 million people at risk [15], and in some areas death rates exceed those of HIV/AIDS and malaria. Trypanosomiasis also has a significant affect on human nutrition through its impact on domesticated animals, for example, killing 3 million cattle per year. In humans, the disease is caused by infection with the sub-species Trypanosoma brucei gambiense (western and central Africa) and Trypanosoma brucei rhodesiense (eastern and southern Africa) and is invariably fatal unless treated. In the past 25 years, only one drug, eflornithine [( $R, S)$-2-difluoromethylornithine (DFMO, initially developed as an anticancer drug)], has been approved for HAT therapy [16]. Moreover, all four front-line drugs (suramin, pentamidine, melarsoprol and eflornithine) require hospitalization for administration, are expensive and are associated with severe side effects. In addition, drug resistance is commonly observed, and suramin and pentamidine are not effective against the later stages of the disease, which occur when parasites gain access to the central nervous system $[17,18]$. Treatment of late stage East African trypanosomiasis is a particular problem, since $T$. $b$. rhodesiense is refractory to eflornithine.
Melarsoprol, which is the only available drug, can cause arsenic encephalopathy with 5-10\% patient mortality [19]. Although there is an urgent need for new anti-trypanosome drugs, the pharmaceutical industry has paid little attention to this relatively unprofitable area. The development of broad-spectrum, inexpensive, highly efficient, and nontoxic drugs therefore remains a priority.

Recently, there have been reports that bloodstream forms of the African trypanosome, $T$. brucei, are sensitive to the anti-influenza virus drug rimantadine $\left(\mathrm{IC}_{50}=7 \mu \mathrm{M}\right)$ and to a lesser extent amantadine. The trypanocidal activity is $\mathrm{pH}$-dependent and is enhanced with increasing alkalinity. Rimantadine is also toxic to the trypanosomatid parasites Trypanosoma cruzi and Leishmania major [20]. More recently, a number of other aminoadamantane derivatives have been evaluated for their trypanocidal properties. These studies revealed a correlation between increased lipophilicity and potency against $T$. brucei (Fig. 1) [9e,f,21]. Here, by investigating the trypanocidal properties of newly synthesized aminoadamantane derivatives, our aim has been to provide greater insight into the chemical features that may enhance this activity.

We now describe the synthesis and biological evaluation of adamantanoaminoalcohols 16, 18, 21, 24, 27, 28, 30, 36 and 37, adamantanodiamines $\mathbf{3 2}, \mathbf{3 5}$ and $\mathbf{4 0}$ and adamantanamines $\mathbf{4 6}$ and 48 (Fig. 2), and show that they contain structural features necessary for antiviral activity.

\section{Results and discussion}

\subsection{Chemistry}

2-Aminomethyl-2-hydroxyadamantane $\mathbf{1 6}$ (Scheme 1) was prepared by known methods from adamantanone in good yields [22].

In order to synthesize the 2-(2-aminoethyl)-2-hydroxyadamantane $\mathbf{1 8}$ we follow a concise and efficient synthesis. In this approach, we have employed $n$-butyl lithium and acetonitrile in dry THF for the preparation of 2-(2-hydroxy-2-adamantyl)acetonitrile 19 from adamantanone 14. In comparison with the other bases reported in the literature [23], the use of $n$-butyl lithium allows the synthesis of the hydroxyl nitrile 19 quantitatively (97\%) without side products and laborious purifications. Nitrile 19 was reduced with $\mathrm{LiAlH}_{4}$ in tetrahydrofuran. As a result, 2-(2-aminoethyl)-2hydroxyadamantane was obtained in great yield, which was isolated as hydrochloride.

The synthesis of the aminoalcohol $\mathbf{2 1}$ is illustrated in Scheme 1. Hydroxymethylation of the 2-nitroadamantane $\mathbf{1 9}$ afforded the 
<smiles>NCC1(O)C2CC3CC(C2)CC1C3</smiles>

16<smiles>NCCC1(O)C2CC3CC(C2)CC1C3</smiles>

18<smiles>NC1(CO)C2CC3CC(C2)CC1C3</smiles>

21<smiles>NCC1(CO)C2CC3CC(C2)CC1C3</smiles>

24<smiles>NCCC1(O)C2CC3CC(C2)CC1C3</smiles><smiles>NCCC12CC3CC(CC(C3)C1O)C2</smiles>

28<smiles>OC1(C2CCCCN2)C2CC3CC(C2)CC1C3</smiles>

30<smiles>CNC1(c2ccccn2)C2CC3CC(C2)CC1C3</smiles>

32<smiles>CNCC(NC)C12CC3CC(CC(C3)C1)C2</smiles><smiles>CN(C)CCCC1(C)CC2CCC(C2)C1O</smiles>

37<smiles>CNCCC1(C)CC2CCC(C2)C1N</smiles><smiles>NC1C2CC3CC(C2)CC1(c1ccccc1)C3</smiles>

36<smiles>NC1CC2CCC1C2</smiles>

48

Fig. 2.

2-nitro-2-adamantanemethanol 20. Catalytic reduction of the nitro alcohol 20 resulted in the 2-amino-2-adamantanemethanol 21.

In order to synthesize the aminoalcohol $\mathbf{2 4}$ (Scheme 1), 2-adamantanecarbonitrile $\mathbf{2 2}$ was used as a starting material [9c]. Thus, lithiation at C-2 using LDA and reaction of the resulting carbanion with methyl chloroformate gave cyanoester 23 in good yield [9e]. Reduction of the latter with $\mathrm{LiAlH}_{4}$ under mild heating afforded the desired aminoalcohol 24, in excellent yield (93\%).

The synthetic route to the aminoalcohol $\mathbf{2 8}$ is shown in Scheme 1 and involved protoadamantanone 25 [24a], prepared by a modification of the literature method from the reaction of 1-adamantanol with iodine and lead tetraacetate [24a,b], which on treatment with $n$-butyl lithium and acetonitrile in dry THF afforded the desired hydroxyl nitrile $\mathbf{2 6}$ in a 95\% yield. Reduction of the latter with $\mathrm{LiAlH}_{4}$ gave aminoalcohol 27. Heating aminoalcohol 27 in dioxane with $\mathrm{H}_{2} \mathrm{SO}_{4}$ (15\%) afforded the target compound 28 in an excellent yield (95\%).

Tertiary alcohol $\mathbf{3 0}$ was synthesized from the reaction of adamantanone $\mathbf{1 4}$ and 2-pyridinyl lithium. Catalytic hydrogenation of the hydrochloride form of $\mathbf{2 9}$ over $\mathrm{PtO}_{2}$ catalyst led to the aminoalcohol 30 [25].

Diamine 32 was prepared starting from adamantanone 14 which was successively transformed to 2-( $N$-methylimino)adamantane 31 (Scheme 2), in 98\% yield, upon treatment with methylamine in dry THF with $3 \AA$ molecular sieves at room temperature under nitrogen overnight [26]. Imine 31 reacted with 2-bromopyridine, $n$-BuLi, in

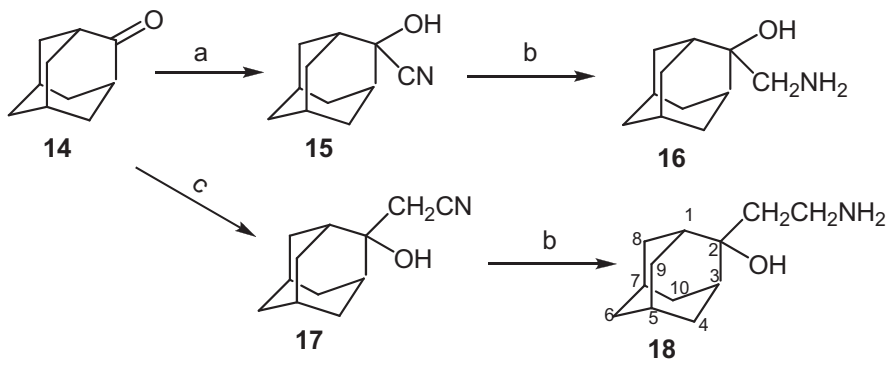<smiles>NC1(CO)C2CC3CC(C2)CC1C3</smiles>

19

20

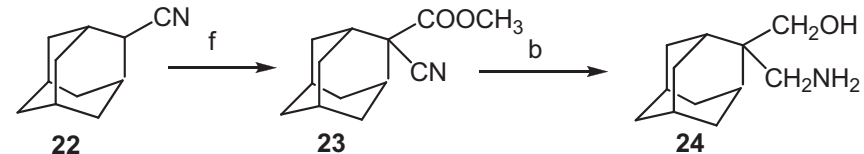<smiles>O=C1CC2CC3CC(C2)CC1C3</smiles>

25

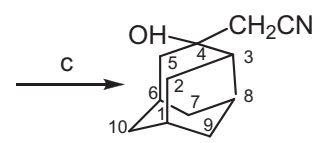

26
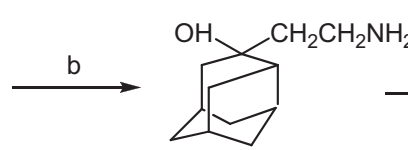

27

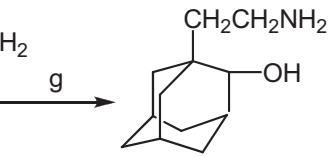

28

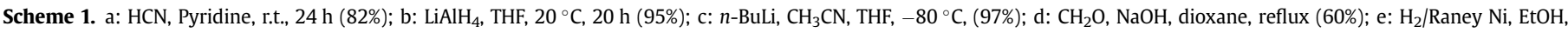
55 p.s.i., $50{ }^{\circ} \mathrm{C}(99 \%)$; f: $\mathrm{LDA},-70^{\circ} \mathrm{C}, \mathrm{THF}, \mathrm{ClCOOCH}_{3}, 24 \mathrm{~h}, 20^{\circ} \mathrm{C}$, (87\%); g: dioxane, $\mathrm{H}_{2} \mathrm{SO}_{4} 15 \%, 80^{\circ} \mathrm{C}, 2 \mathrm{~h}(96 \%)$. 
the present of 1-(2-methoxyphenoxy)-N,N-dimethyl-3-phenylpropan-2-amine to give the target diamine $\mathbf{3 2}$.

The Strecker reaction [27] has been employed for the preparation of diamine 35 (Scheme 2). The conditions for preparing the latter are consistent with mixing the bulky 1-adamantanecarboxaldehyde 33 with $\mathrm{NaCN}$ and $\mathrm{CH}_{3} \mathrm{NH}_{2}$, in a mixture of DMSO/water, and leaving the mixture to react at ambient temperature. Catalytic hydrogenation of the $\alpha$-aminonitrile 34 over $\mathrm{PtO}_{2}$ provided the desired $\alpha$-aminomethyl adamantanemethanamine 35 [28].

The key intermediate $\mathbf{3 6}$ for the synthesis of compounds $\mathbf{3 7}$ and 40 was prepared from protoadamantanone 25, which was first converted to the aminoalcohol $\mathbf{3 6}$ via a Grignard reaction between ketone 25 and the magnesium derivative of 3-chloro- $N, N$-dimethylpropan-1-amine hydrochloride (Scheme 2). Heating aminoalcohol 36 in dioxane with $\mathrm{H}_{2} \mathrm{SO}_{4}(15 \%)$ afforded compound 37 quantitatively via a $\mathrm{C} 2-\mathrm{C} 3$ to $\mathrm{C} 4$ metathesis [24b]. Oxidation of the latter under Jones reaction conditions led to the aminoketone $\mathbf{3 8}$, which was in turn converted to the respective oxime 39. Catalytic hydrogenation of $\mathbf{3 9}$ over Raney Nickel afforded diamine $\mathbf{4 0}$ in a $91 \%$ yield.

The synthesis of analogue $\mathbf{4 6}$ is shown in Scheme 3. Protoadamantanone 25, was treated with phenyl lithium to give the corresponding tertiary alcohol $\mathbf{4 1}$ as an endo/exo (1:1) isomeric mixture in $96 \%$ yield, which on treatment with formic acid was converted to formate $\mathbf{4 2}$ via a $\mathrm{C} 2-\mathrm{C} 3$ to $\mathrm{C} 4$ metathesis. Saponification of the in situ formed ester $\mathbf{4 2}$ gave the respective secondary alcohol 43 in 96\% yield, and that was then oxidized under Jones reaction conditions to the corresponding 1-phenyl-2-one 44 [9d]. Treatment of ketone $\mathbf{4 4}$ with hydroxylamine hydrochloride in the presence of sodium acetate led to the formation of the respective oxime 45 quantitatively, which on hydrogenation over Raney $\mathrm{Ni}$ catalyst was converted to amine $\mathbf{4 6}$, the yield of the latter was found to increase upon heating and prolonged hydrogenation.

Finally, treatment of ketone $\mathbf{2 5}$ with hydroxylamine hydrochloride in the presence of sodium acetate led to the formation of the respective oxime 47 , which on hydrogenation over Raney $\mathrm{Ni}$ catalyst was converted to protoadamantanamine $\mathbf{4 8}$.

\section{Biological activity}

The antiviral efficacy of the new aminoadamantane derivatives $16,18,21,24,27,28,30,32,35,36,37,40,46$ and 48 was determined in vitro against influenza $\mathrm{A}$ (H3N2 subtype; strain A/HK/7/87, which carries a serine at position 31 of the M2 protein) and was compared to the activity of amantadine, rimantadine and ribavirin (Table 1). The antiviral assay used was identical to that previously reported [29], and is based on inhibition of the virus-induced cytopathic effect (CPE) after multiple replication cycles at $72 \mathrm{~h}$ post infection, as<smiles>CN=C1C2CC3CC(C2)CC1C3</smiles><smiles>CNCC1(C(C)NC)CC2CC3CC(C2)CC(C(CN)NC)(C3)C1</smiles><smiles>O=C1CC2CC3CC(C2)CC1C3</smiles>

25

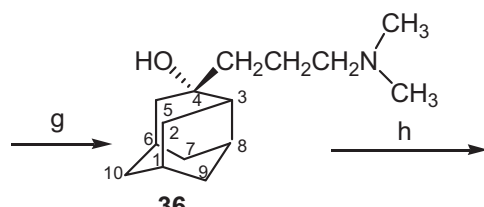

36<smiles>CNCCC1(C)C2CCCC(C2)C1O</smiles>

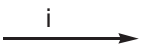<smiles>CNCCC12CC3CC(CC(C3)C1=O)C2</smiles>

38

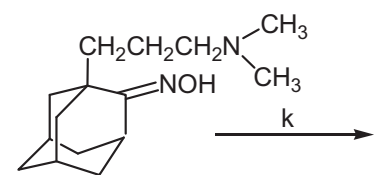

39<smiles>CNCCC1(C)C2CC3CC(C2)CC1C3</smiles>

Scheme 2. a: 2-pyridinyl lithium, $\mathrm{Et} 2 \mathrm{O} / \mathrm{THF},-60{ }^{\circ} \mathrm{C}(82 \%)$; b: (1) gas $\mathrm{HCl}$, EtOH; (2) $\mathrm{H}_{2} / \mathrm{PtO}_{2}$, EtOH and then $\mathrm{Na}_{2} \mathrm{CO}_{3} 10 \%(97 \%)$; c: $\mathrm{CH}_{3} \mathrm{NH}_{2}$, THF, molecular sieves (3 $\AA$ ), $24 \mathrm{~h}$ ( $82 \%$ ); d: 2-bromopyridine, $n$-BuLi, dry ether, 1-(2-methoxyphenoxy)- $N, N$-dimethyl-3-phenylpropan-2-amine, dry toluene, $3 \mathrm{~h}(53 \%)$; e: $\mathrm{NaCN}_{2} \mathrm{CH}_{3} \mathrm{NH}_{3}^{+} \mathrm{Cl}^{-}, \mathrm{DMSO} / \mathrm{H}_{2} \mathrm{O} 29: 1, \mathrm{rt}, 48 \mathrm{~h}$, and then $\mathrm{HCl}(\mathrm{g}) / \mathrm{Et}_{2} \mathrm{O}$ (66\%); f: $\mathrm{H}_{2}, \mathrm{PtO}_{2}, \mathrm{HCl}(\mathrm{g}) / \mathrm{MeOH}, 45 \mathrm{lb} / \mathrm{in}^{2}$, rt, $6 \mathrm{~h}$, and then $\mathrm{NaOH} 20 \%$ (85\% for 8, 90\% for 11); g: $\left(\mathrm{CH}_{3}\right)_{2} \mathrm{NCH}_{2} \mathrm{CH}_{2} \mathrm{CH}_{2} \mathrm{MgCl}, \mathrm{THF}, \mathrm{C}_{6} \mathrm{H}_{6}$, reflux, $4 \mathrm{~h}(97 \%)$; h: dioxane, $\mathrm{H}_{2} \mathrm{SO}_{4} 15 \%, 80^{\circ} \mathrm{C}, 2 \mathrm{~h}(93 \%)$; i: $\mathrm{CrO}_{3}$, aq. $\mathrm{H}_{2} \mathrm{SO}_{4}(1 \mathrm{~N})$, acetone, $15^{\circ} \mathrm{C}$, then r.t., $24 \mathrm{~h}(87 \%)$; j: $\mathrm{NH}_{2} \mathrm{OH}-\mathrm{HCl}, \mathrm{CH}_{3} \mathrm{COONa} .3 \mathrm{H}_{2} \mathrm{O}$, abs. EtOH, $\mathrm{H}_{2} \mathrm{O}$ (14:1), $3 \mathrm{~h}$, reflux (quantitative); k: EtOH, Ni-Raney, 55 p.s.i., $65^{\circ} \mathrm{C}, 5 \mathrm{~h}(95 \%)$. 


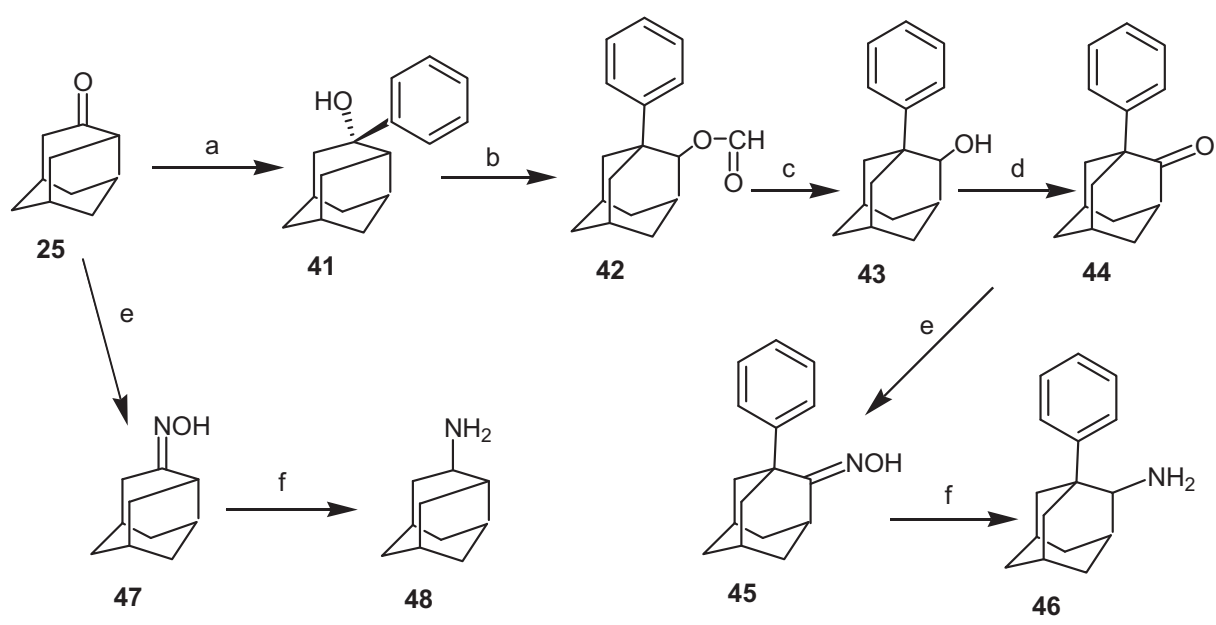

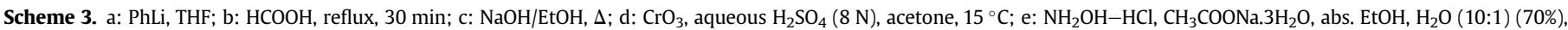
$3 \mathrm{~h}$, reflux (quantitative); f: EtOH, Ni-Raney, 55 p.s.i., $90^{\circ} \mathrm{C}, 8 \mathrm{~h}(70-81 \%)$.

assessed by microscopical scoring of the CPE and a formazan-based cell viability assay. There was a good correlation between the antiviral $\mathrm{EC}_{50}$ values obtained by the $\mathrm{CPE}$ reduction and MTS cell viability assay, and, hence, only the latter values are shown in Table 1.

The data presented in Table 1 indicate that compounds $\mathbf{2 1}$ and 24 elicit potent anti-influenza A virus activity, with a selectivity index (SI) of at least 314 and 256, respectively. Aminoalcohol 24 was endowed with the most potent anti-influenza A virus activity; it proved to be at least 6 -fold more potent than amantadine, equipotent to rimantadine and 26 -fold more active than ribavirin. Protoadamantanamine $\mathbf{4 8}$ was less active than rimantadine, while this compound was comparable to amantadine in both antiviral

Table 1

Anti-influenza A virus (H3N2) activity and cytotoxicity of aminoadamantane derivatives $^{\mathrm{a}}$ in MDCK cells. ${ }^{\mathrm{b}}$

\begin{tabular}{llcc}
\hline Compound & $\mathrm{EC}_{50}{ }^{\mathrm{c}, \mathrm{e}}(\mu \mathrm{M})$ & $\mathrm{MCC}^{\mathrm{d}}(\mu \mathrm{M})$ & $\mathrm{SI}\left(\right.$ ratio $\left.\mathrm{MCC} / \mathrm{EC}_{50}\right)$ \\
\hline $\mathbf{1 6}$ & $\mathrm{N} / \mathrm{A}$ & - & - \\
$\mathbf{1 8}$ & $6.24 \pm 7.80(4)$ & 17 & 3 \\
$\mathbf{2 1}$ & $1.46 \pm 0.27(3)$ & $>459$ & $>314$ \\
$\mathbf{2 4}$ & $0.34 \pm 0.12(4)$ & 87 & 256 \\
$\mathbf{2 7}$ & $7.68 \pm 1.68(3)$ & 512 & 67 \\
$\mathbf{2 8}$ & $8.60 \pm 1.99(3)$ & 512 & 60 \\
$\mathbf{3 0}$ & $\mathrm{N} / \mathrm{A}$ & 208 & - \\
$\mathbf{3 2}$ & $\mathrm{N} / \mathrm{A}$ & 264 & - \\
$\mathbf{3 5}$ & $\mathrm{N} / \mathrm{A}$ & 404 & - \\
$\mathbf{3 6}$ & $\mathrm{N} / \mathrm{A}$ & $>250$ & - \\
$\mathbf{3 7}$ & $\mathrm{N} / \mathrm{A}$ & $>250$ & - \\
$\mathbf{4 0}$ & $\mathrm{N} / \mathrm{A}$ & 200 & - \\
$\mathbf{4 6}$ & $\mathrm{N} / \mathrm{A}$ & 218 & - \\
$\mathbf{4 8}$ & $1.5 \pm 0.3(4)$ & 107 & 69 \\
Amantadine & 2.0 & $>100$ & $>51$ \\
Rimantadine & $\leq 0.362$ & $>100$ & $>276$ \\
Ribavirin & 8.7 & 20 & 2 \\
\hline
\end{tabular}

$\mathrm{N} / \mathrm{A}$ : not active at subtoxic concentrations or the highest concentration tested $(\sim 500 \mu \mathrm{M})$.

a All compounds were tested as hydrochlorides. Aminoalcohols $\mathbf{2 7}$ and $\mathbf{3 6}$ were tested as free bases.

b MDCK, Madin-Darby canine kidney cells; virus strain: influenza A/Hong Kong/7/ 87 (H3N2).

c Concentration producing $50 \%$ inhibition of virus-induced cytopathic effect, as determined by measuring the cell viability with the colorimetric formazan-based MTS assay.

${ }^{\mathrm{d}}$ Minimal cytotoxic concentration, or concentration that causes microscopically detectable changes in cell morphology.

e Data are shown as mean $\pm S D$ (in brackets: number of independent determinations). activity and cytotoxicity. Aminoalcohol 18, 27, and its metathesis product 28, had intermediate activity $\left(\mathrm{EC}_{50}\right.$ ranging from 6 to $\left.9 \mu \mathrm{M}\right)$, with 27 and 28 having promising selectivity (SI above 60). Compounds 16, 30, 32, 35, 36, 37, 40 and 46 were devoid of antiinfluenza virus activity.

All compounds were inactive against influenza B virus, which is in accordance with their putative mode of action, namely interaction with the influenza A virus M2 protein, which is different in influenza B virus. This is further supported by our observation that none of the new derivatives displayed activity against the influenza virus strain X-31, which carries the V27T and S31N substitutions in $\mathrm{M} 2$, associated with amantadine resistance.

The numbered compounds in Table 2 were first tested at $5 \mu \mathrm{g} \mathrm{ml}^{-1}$ against bloodstream form $T$. brucei (strain 427) cultured at $\mathrm{pH}$ 7.4. Compounds displaying significant inhibitory activity $(>50 \%)$ at this concentration were assessed further and their $\mathrm{IC}_{50}$ and $\mathrm{IC}_{90}$ values determined (Experimental section). The values shown are the mean \pm standard deviation from three experiments, with the values for rimantadine shown for comparison. N/A: compounds with marginal activity at $5 \mu \mathrm{g} \mathrm{ml}^{-1}$ which were not examined further.

In the preliminary screen, bloodstream form $T$. brucei, were cultured for 2 days in the presence of aminoadamantane derivatives at $5 \mu \mathrm{g} \mathrm{ml}^{-1}(20-30 \mu \mathrm{M}$, depending on the compound). At this

Table 2

Susceptibility of cultured bloodstream form $T$. brucei to aminoadamantane derivatives.

\begin{tabular}{lll}
\hline Compound & $\mathrm{IC}_{50}(\mu \mathrm{M})$ & $\mathrm{IC}_{90}(\mu \mathrm{M})$ \\
\hline $\mathbf{1 6}$ & $\mathrm{N} / \mathrm{A}$ & - \\
$\mathbf{1 8}$ & $\mathrm{N} / \mathrm{A}$ & - \\
$\mathbf{2 1}$ & $9.4 \pm 1.1$ & $18.2 \pm 1.1$ \\
$\mathbf{2 4}$ & $\mathrm{N} / \mathrm{A}$ & - \\
$\mathbf{2 7}$ & $\mathrm{N} / \mathrm{A}$ & - \\
$\mathbf{2 8}$ & $\mathrm{N} / \mathrm{A}$ & - \\
$\mathbf{3 0}$ & $\mathrm{N} / \mathrm{A}$ & - \\
$\mathbf{3 2}$ & $24.6 \pm 0.7$ & $>25$ \\
$\mathbf{3 5}$ & $5.2 \pm 0.4$ & $7.8 \pm 0.4$ \\
$\mathbf{3 6}$ & $0.84 \pm 0.04$ & $1.7 \pm 0.1$ \\
$\mathbf{3 7}$ & $0.84 \pm 0.08$ & $1.8 \pm 0.1$ \\
$\mathbf{4 0}$ & $\mathrm{N} / \mathrm{A}$ & - \\
$\mathbf{4 6}$ & $11.1 \pm 5.7$ & $>20$ \\
$\mathbf{4 8}$ & N/A & - \\
Rimantadine & $7.0 \pm 0.1$ & $14.0 \pm 1.7$ \\
\hline
\end{tabular}


concentration, compounds $16,18,24,27,28,30,40$ and 48 showed only slight inhibition (up to $30 \%$ ) of parasite growth, while dianamine 32 was marginally more active (Table 2). In contrast, amine 46, aminoalcohol 21 and diamine 35 each exhibited trypanocidal activity in a concentration range similar to that of rimantadine, with lysis of all trypanosomes in the culture at $5 \mu \mathrm{g} \mathrm{ml}^{-1}$. Aminoalcohols $\mathbf{3 6}$ and $\mathbf{3 7}$ were the most active of the compounds tested. They displayed significant trypanocidal activity at sub-micromolar levels and were found to be approximately 10 -fold more potent than rimantadine (Table 2 ).

The targets of adamantane derivatives in trypanosomes are unknown. Likewise, the mechanisms of action of other trypanocidal drugs, including pentamidine, suramin and melarsoprol have yet to been identified [30]. However, the mode of action of the nitroheterocycle nifurtimox has been resolved [31]. This drug, in combination with eflornithine, is now recommended as the treatment of choice for late stage West African sleeping sickness [32]. Nifurtimox-resistance is due to down-regulation of the type I nitroreductase which activates the drug in vivo. There is no crossresistance with rimantadine [31].

\section{Conclusion}

The major conclusions from this study can be summarized as follows: (a) Introduction of the hydroxyl group adjacent to the amine resulted in good antiviral activity, comparable to that of rimantadine. (b) It is apparent that for a series of aminoadamantane compounds, the relative antiviral activity is not directly comparable to the relative trypanocidal potencies in cell culture. (c) The two most active adamantane analogues identified in this report, 36 and 37, illustrate the synergistic effect on anti-trypanosome activity of the lipophilic character of the side chain and the hydroxyl group. Finally, the simultaneous anti-influenza virus A and trypanocidal activity of aminoalcohol 21, along with its very low cytotoxicity, are of particular interest and merit further investigation.

\section{Experimental}

Melting points were determined using a Büchi capillary apparatus and are uncorrected. IR spectra were recorded on a Perkin-Elmer 833 spectrometer. ${ }^{1} \mathrm{H}$ and ${ }^{13} \mathrm{C}$ NMR spectra were recorded on a Bruker MSL 400 spectrometer, respectively, using $\mathrm{CDCl}_{3}$ as solvent and TMS as internal standard. Carbon multiplicities were established by DEPT experiments. The 2D NMR experiments (HMQC, COSY and NOESY) were performed for the elucidation of the structures of the new compounds.

Microanalyses were carried out by the Service Central de Microanalyse (CNRS) France, and the results obtained had a maximum deviation of $\pm 0.4 \%$ from the theoretical value.

\subsection{2-Hydroxy-tricyclo[3.3.1.1]decane-2-acetonitrile (17) [3,7]}

To a stirred solution of $n$-butyl lithium $2.5 \mathrm{M}$ in hexanes $(22 \mathrm{ml}$, $50 \mathrm{mmol})$, in dry THF (22 ml) was added, over a period of $7 \mathrm{~min}$, a solution of acetonitrile $(2.05 \mathrm{~g}, 50 \mathrm{mmol})$ in dry THF $(50 \mathrm{ml})$ at $-80^{\circ} \mathrm{C}$ under an argon atmosphere. After stirring the mixture for $1 \mathrm{~h}$ at $-80^{\circ} \mathrm{C}$, a solution of adamantanone 1 ( $\left.7.50 \mathrm{~g}, 50 \mathrm{mmol}\right)$, in dry THF $(50 \mathrm{ml})$ was added over a period of $5 \mathrm{~min}$. The cold bath was removed and the resulting suspension was stirred for $10 \mathrm{~min}$. The mixture was treated with ice-water $(50 \mathrm{ml})$ and concd $\mathrm{HCl}$ $(5 \mathrm{ml})$, extracted with $\mathrm{Et}_{2} \mathrm{O}(3 \times 50 \mathrm{ml})$ and the organic phase was washed with water $(40 \mathrm{ml})$, dried $\left(\mathrm{Na}_{2} \mathrm{SO}_{4}\right)$ and concentrated in vacuo to afford $9.26 \mathrm{~g}$ of the solid hydroxy nitrile $2(97 \%), \mathrm{mp} 140{ }^{\circ} \mathrm{C}$ (THF - petr. ether). I.R. (Nujol): $v$ : (OH) 3437, (CN) $2259 \mathrm{~cm}^{-1} \cdot{ }^{1} \mathrm{H}$ $\operatorname{NMR}\left(400 \mathrm{MHz}, \mathrm{CDCl}_{3}\right.$ ): 1.62 (br d, 2H, H-4e, 9e), 1.71 (br d, 4H, H-6,
8), 1.83 (br d, $4 \mathrm{H}, \mathrm{H}-5,7,10$ ), 1.91 (br s, $2 \mathrm{H}, \mathrm{H}-1,3$ ), 2.18 (br d, 3H, H4a, 9a, OH), 2.77 (s, 2H, CH$-\mathrm{CN}$ ); $\left.{ }^{13} \mathrm{C} \mathrm{NMR} \mathrm{(100} \mathrm{MHz,} \mathrm{CDCl}_{3}\right): 26.6$ (C-5), 26.8 (C-7), $28.9\left(\mathrm{CH}_{2}-\mathrm{CN}\right), 32.4(\mathrm{C}-4,9), 34.4(\mathrm{C}-8,10), 36.7$ (C1, 3), 37.7 (C-6), 73.9 (C-2), $117.7(\mathrm{CN})$. Anal. Calcd. for $\mathrm{C}_{12} \mathrm{H}_{17} \mathrm{NO}$. Calcd, \%: C 75.35; H 8.96. Found, \%: C 75.33; H 8.90.

\subsection{2-(2-Aminoethyl)tricyclo[3.3.1.1]decan-2-ol (18) [3,7]}

To a stirred suspension of $\mathrm{LiAlH}_{4}(1.50 \mathrm{~g}, 31 \mathrm{mmol})$, in dry THF $(20 \mathrm{~mL})$ was added dropwise a solution of hydroxy nitrile $\mathbf{2}(1.13 \mathrm{~g}$, $5.9 \mathrm{mmol})$ in dry THF $(10 \mathrm{ml})$. The reaction mixture was stirred for $20 \mathrm{~h}$ at $20^{\circ} \mathrm{C}$ and then hydrolyzed with water and $\mathrm{NaOH}(10 \%)$, under ice cooling, and dried $\left(\mathrm{Na}_{2} \mathrm{CO}_{3}\right)$. The inorganic precipitate was filtered off and washed with THF; the filtrate was concentrated in vacuo $\left(T<40^{\circ} \mathrm{C}\right)$ to give $1.13 \mathrm{~g}$ of the solid aminoalcohol 4 (quantitative yield), $\mathrm{mp} 131^{\circ} \mathrm{C}$ (ether). I.R. (Nujol): $v$ : 3349, 3269, $3171 \mathrm{~cm}^{-1}$. ${ }^{1} \mathrm{H} \mathrm{NMR}$ (400 MHz, $\mathrm{CDCl}_{3}$ ): 1.47 (br d, 2H, H-4e, 9e), 1.67 (br d, 4H, H-6, 8), 1.77 (br t, 8H, H-1, 3, 5, 7, 10, $\mathrm{CH}_{2} \mathrm{CH}_{2} \mathrm{NH}_{2}$ ), 2.27 (br d, $2 \mathrm{H}, \mathrm{H}-4 \mathrm{a}, 9 \mathrm{a}), 2.98$ (t, $\left.2 \mathrm{H}, \mathrm{J}=11.6 \mathrm{~Hz}, \mathrm{CH}_{2} \mathrm{CH}_{2} \mathrm{NH}_{2}\right) ;{ }^{13} \mathrm{C} \mathrm{NMR}$ (100 MHz, $\mathrm{CDCl}_{3}$ ): 27.4 (C-5), 27.6 (C-7), 32.7 (C-4, 9), 34.6 (C-8, 10), $37.0\left(\mathrm{CH}_{2} \mathrm{CH}_{2} \mathrm{NH}_{2}\right), 37.3\left(\mathrm{CH}_{2} \mathrm{CH}_{2} \mathrm{NH}_{2}\right), 37.5(\mathrm{C}-1,3), 38.5$ (C-6), 75.5 (C-2). Anal. Calcd. for $\mathrm{C}_{12} \mathrm{H}_{22} \mathrm{NOCl}$. Calcd, \%: C 62.19; $\mathrm{H}$ 9.57. Found, \%: C 62.42; H 9.63.

\subsection{2-Cyano- tricyclo[3.3.1.1]decane-2-carboxylic acid methyl ester (23) $[3,7]$}

A solution of nitrile $22(14.20 \mathrm{~g}, 88.0 \mathrm{mmol})$ in dry THF $(60 \mathrm{ml})$ was added dropwise to a solution of LDA, prepared by adding a dry THF solution of freshly distilled diisopropylamine $(17.20 \mathrm{~g}$, $170.5 \mathrm{mmol}$ ) to a solution of $n-\mathrm{BuLi}(54.52 \mathrm{ml}, 2.5 \mathrm{M}$ or $60 \mathrm{mmol})$ in hexane and stirring the resulting solution for $30 \mathrm{~min}$ at $-70{ }^{\circ} \mathrm{C}$ under an argon atmosphere. After stirring the mixture for $2 \mathrm{~h}$, a solution of freshly distilled methyl chloroformate ( $48.28 \mathrm{~g}$, $510 \mathrm{mmol})$ in dry THF (50 ml) was added and the mixture was stirred overnight to slowly reach room temperature. The solution was then poured into crashed ice, extracted with ether; the organic phase was washed with water and brine, dried $\left(\mathrm{Na}_{2} \mathrm{SO}_{4}\right)$ and evaporated under reduced pressure. The crude oil was purified by vacuum distillation $\left(\mathrm{bp}_{0.01}=120^{\circ} \mathrm{C}\right.$ ) to afford $16.85 \mathrm{~g}$ (88\%) of ester 23 as a low melting point solid. $\mathrm{mp} 45^{\circ} \mathrm{C}$ ( $\mathrm{Et}_{2} \mathrm{O}-n$-pentane); I.R.(Nujol): $v(\mathrm{CN}) 2238,(\mathrm{C}=\mathrm{O}) 1741 \mathrm{~cm}^{-1} ;{ }^{1} \mathrm{H}$ NMR $(400 \mathrm{MHz}$, $\left.\mathrm{CDCl}_{3}\right), \delta(\mathrm{ppm}) 1.65-2.15(\mathrm{~m}, 12 \mathrm{H}, \mathrm{H}-4,5,6,7,8,9,10), 2.44$ (br s, $2 \mathrm{H}, \mathrm{H}-1,3), 3.74$ (s, 3H, $\mathrm{CH}_{3}$ ).

\subsection{2-(2-Aminoethyl)tricyclo[3.3.1.1]decan-2-ol (24) [3,7]}

To a stirred suspension of $\mathrm{LiAlH}_{4}(10.6 \mathrm{~g}, 279 \mathrm{mmol})$ in dry THF $(150 \mathrm{ml})$ was added dropwise a solution of the cyanoester 23 $(14.8 \mathrm{~g}, 67.5 \mathrm{mmol})$ in dry THF $(150 \mathrm{ml})$. The reaction mixture was refluxed for $30 \mathrm{~h}$ and then hydrolyzed with water and $\mathrm{NaOH}(10 \%)$ under ice cooling and dried $\left(\mathrm{Na}_{2} \mathrm{CO}_{3}\right)$. The inorganic precipitate was filtered off, washed with THF, and the filtrate was concentrated in vacuo. The liquid residue dissolved in ether $(150 \mathrm{ml})$ and extracted with $\mathrm{HCl} 5 \%(100 \mathrm{ml})$ (the aqueous layer must be kept acid). The aqueous layer extracted with ether and alkalized with $\mathrm{KOH} 30 \%$ under ice cooling. The solution was cooled and the precipitated aminoalcohol $\mathbf{2 4}$ was filtered, washed with cool water and dried: yield $12.3 \mathrm{~g}$ (93\%); $\mathrm{mp} 133^{\circ} \mathrm{C}$ (THF- $n$-pentane); IR (Nujol) $v$ $3378 \mathrm{~cm}^{-1}, 3175 \mathrm{~cm}^{-1}(\mathrm{OH}) ;{ }^{1} \mathrm{H} \mathrm{NMR}\left(400 \mathrm{MHz}, \mathrm{CDCl}_{3}\right), \delta: 1.51$ (br t, $4 \mathrm{H}, \mathrm{H}-4 \mathrm{e}, 8,9 \mathrm{e}$ ), 1.64 (br d, 4H, H-1, 3, 6), 1.81 (br s, 2H, H-5, 7), 1.89 (br d, 1H, H-10), 2.00 (br d, 2H, H-4a, 9a), 2.59 (br s, $2 \mathrm{H}, \mathrm{NH}_{2}$ ), 3.04 (s, $2 \mathrm{H}, \mathrm{CH}_{2} \mathrm{NH}_{2}$ ), 3.83 (br s, $\left.2 \mathrm{H}, \mathrm{CH}_{2} \mathrm{OH}\right)(\mathrm{ppm}) ;{ }^{13} \mathrm{C} \mathrm{NMR}\left(\mathrm{CDCl}_{3}\right.$, $100 \mathrm{MHz}$ ), $\delta$ : 28.0 (C-5), 28.2 (C-7), 29.8 (C-1, 3), 32.7 (C-4, 9), 32.9 $(\mathrm{C}-8,10), 39.4(\mathrm{C}-6), 40.9(\mathrm{C}-2), 48.8\left(\mathrm{CH}_{2} \mathrm{NH}_{2}\right), 70.8\left(\mathrm{CH}_{2} \mathrm{OH}\right)(\mathrm{ppm})$. 
Anal. Calcd. for $\mathrm{C}_{12} \mathrm{H}_{22} \mathrm{NOCl}$ Calcd. (\%): C: 62.19, H: 9.57, N: 6.04 . Found (\%): C: 62.48, H: 6.50, N: 5.87.

\subsection{4-Hydroxy-tricyclo[4.3.1.0]decan-4-acetonitrile (26) [3,8]}

To a stirred solution of $n$-butyl lithium $2.5 \mathrm{M}$ in hexanes ( $10.6 \mathrm{ml}, 26.6 \mathrm{mmol})$, in dry THF $(10 \mathrm{ml})$ was added, over a period of $4 \mathrm{~min}$, a solution of acetonitrile $(1.09 \mathrm{~g}, 26.6 \mathrm{mmol})$ in dry THF $(20 \mathrm{ml})$ at $-80^{\circ} \mathrm{C}$ under an argon atmosphere. After stirring the mixture for $1 \mathrm{~h}$ at $-80^{\circ} \mathrm{C}$, a solution of protoadamantanone 25 $(2.0 \mathrm{~g}, 13.3 \mathrm{mmol})$, in dry THF $(20 \mathrm{ml})$ was added over a period of $10 \mathrm{~min}$. The cold bath was removed and the resulting suspension was stirred for $10 \mathrm{~min}$. The mixture was treated with ice-water $(50 \mathrm{ml})$, extracted with $\mathrm{Et}_{2} \mathrm{O}(3 \times 30 \mathrm{ml})$ and the organic phase was washed with water $(3 \times 10 \mathrm{ml})$, dried $\left(\mathrm{Na}_{2} \mathrm{SO}_{4}\right)$ and concentrated in vacuo. The residue was purified by flash column chromatography using as eluents $\mathrm{Et}_{2} \mathrm{O}-n$-hexane $2 / 1$ to afford $2.83 \mathrm{~g}$ of the solid hydroxy nitrile $\mathbf{2 6}(95 \%), \mathrm{mp} 61{ }^{\circ} \mathrm{C}\left(\mathrm{Et}_{2} \mathrm{O}-n\right.$-pentane). I.R. (Nujol): $v$ $3464 \mathrm{~cm}^{-1}(\mathrm{OH}), 2253 \mathrm{~cm}^{-1}(\mathrm{CN})$; ${ }^{1} \mathrm{H}$ NMR $\left(400 \mathrm{MHz}, \mathrm{CDCl}_{3}\right)$ endo-exo, $\delta(\mathrm{ppm}$ ) $1.22-2.16$ (complex $\mathrm{m}, 12 \mathrm{H}, \mathrm{H}-1,2,5,6,7,9 \mathrm{e}, 10$, $\mathrm{OH}), 2.30-2.36$ (q, $2 \mathrm{H}, \mathrm{H}-3,8), 2.52-2.72\left(\mathrm{~m}, 3 \mathrm{H}, \mathrm{H}-9 \mathrm{a}, \mathrm{CH}_{2} \mathrm{CN}\right) ;{ }^{13} \mathrm{C}$ NMR $\left(\mathrm{CDCl}_{3}, 100 \mathrm{MHz}\right), \delta(\mathrm{ppm}) 28.2 / 29.2(\mathrm{C}-6), 32.0\left(\mathrm{CH}_{2} \mathrm{CN}\right), 33.0$ (C-8), 33.6/34.3 (C-9), 35.3/35.6 (C-1), 35.8 (C-2), 39.5/39.6 (C-10), 41.6/41.8 (C-7), 42.2/42.6 (C-5), 44.7/45.5 (C-3), 72.2/73.6 (C-4), 118.0/118.2 (CN). Anal. Calcd. for $\mathrm{C}_{12} \mathrm{H}_{17} \mathrm{NO}$ Calcd. (\%): C: $75.35, \mathrm{H}$ : 8.96, N: 7.32. Found (\%): C: 75.12, H: 8.89, N: 7.67.

\subsection{4-(2-Aminoethyl)tricyclo[4.3.1.0]decan-4-ol (27) [3,8]}

To a stirred suspension of $\mathrm{LiAlH}_{4}(2.00 \mathrm{~g}, 52.0 \mathrm{mmol})$, in dry ether $(30 \mathrm{ml})$ was added dropwise a solution of hydroxy nitrile $\mathbf{2 6}$ $(2.21 \mathrm{~g}, 11.5 \mathrm{mmol})$ in dry ether $(20 \mathrm{ml})$. The reaction mixture was stirred for $20 \mathrm{~h}$ at $20^{\circ} \mathrm{C}$ and then hydrolyzed with water and $\mathrm{NaOH}$ (10\%), under ice cooling, and dried $\left(\mathrm{Na}_{2} \mathrm{CO}_{3}\right)$. The inorganic precipitate was filtered off and washed with ether; the filtrate was concentrated in vacuo $\left(T<40^{\circ} \mathrm{C}\right)$ to give $2.15 \mathrm{~g}$ of the solid aminoalcohol 27 (yield 95\%), mp $100{ }^{\circ} \mathrm{C}$ ( $\mathrm{Et}_{2} \mathrm{O}$-n-pentane), I.R.(Nujol) $v$ $3364 \mathrm{~cm}^{-1}(\mathrm{OH}), 3290 \mathrm{~cm}^{-1}\left(\mathrm{NH}_{2}\right) ;{ }^{1} \mathrm{H}$ NMR $\left(400 \mathrm{MHz}, \mathrm{CDCl}_{3}\right)$ endo-exo, $\delta$ (ppm) $1.25-2.00$ (complex $\mathrm{m}, 14 \mathrm{H}, \mathrm{H}-2,5,6,7,9,10$, $\left.\mathrm{CH}_{2} \mathrm{CH}_{2} \mathrm{NH}_{2}, \mathrm{OH}\right), 2.07-2.11(\mathrm{t}, 1 \mathrm{H}, \mathrm{H}-1), 2.22-2.30(\mathrm{~m}, 2 \mathrm{H}, \mathrm{H}-3,8)$, 2.74 (br s, $\left.2 \mathrm{H}, \mathrm{NH}_{2}\right), 3.00-3.04\left(\mathrm{~m}, 2 \mathrm{H}, \mathrm{CH}_{2} \mathrm{NH}_{2}\right) ;{ }^{13} \mathrm{C} \mathrm{NMR}\left(\mathrm{CDCl}_{3}\right.$, $100 \mathrm{MHz}$ ), $\delta$ (ppm) 28.7/29.7 (C-6), 32.6 (C-9), 33.3/33.6 (C-8), 33.9/ 35.3 (C-2), 35.4/35.8 (C-1), 37.8/38.3 $\left(\mathrm{CH}_{2} \mathrm{NH}_{2}\right), 40.0 / 40.1(\mathrm{C}-10)$, 42.3/42.6 (C-7), 42.6/42.8 (C-5), 42.9/43.1 $\left(\mathrm{CH}_{2} \mathrm{CH}_{2} \mathrm{NH}_{2}\right), 45.3 / 45.5$ (C-3), 74.4/75.5 (C-4). Anal. Calcd. for $\mathrm{C}_{12} \mathrm{H}_{21} \mathrm{NO}$ Calcd. (\%): C: 73.80, H: 10.84, N: 7.17. Found (\%): C: 73.71, H: 10.81, N: 7.27.

\subsection{1-(2-Aminoethyl)tricyclo[3.3.1.1]decan-2-ol (28) [3,7]}

A solution of aminoalcohol $27(1.10 \mathrm{~g}, 5.64 \mathrm{mmol})$, dioxane (13 ml) and $\mathrm{H}_{2} \mathrm{SO}_{4} 10 \%(4 \mathrm{ml})$ was heated for $2 \mathrm{~h}$ in a steam bath. After evaporation of the dioxani in vacuo, water was added and the mixture was alkalized with a solution of $\mathrm{NaOH} 20 \%$. The aqueous solution was extracted with ether $(3 \times 25 \mathrm{ml})$, dried $\left(\mathrm{Na}_{2} \mathrm{CO}_{3}\right)$ and concentrated in vacuo to give aminoalcohol 28 as a white solid (1.05 g, 96\%). Mp $87^{\circ} \mathrm{C}\left(\mathrm{Et}_{2} \mathrm{O}-n\right.$-hexane), I.R.(Nujol): $v 3358 \mathrm{~cm}^{-1}$, $3282 \mathrm{~cm}^{-1}(\mathrm{NH}) ;{ }^{1} \mathrm{H}$ NMR $\left(400 \mathrm{MHz}, \mathrm{CDCl}_{3}\right), \delta(\mathrm{ppm}) 0.98-1.00(\mathrm{~d}$, $1 \mathrm{H}, \mathrm{H}-9 \mathrm{e}$ ), $1.12-1.15\left(\mathrm{~m}, 1 \mathrm{H}, \mathrm{CH}_{A} \mathrm{CH}_{2} \mathrm{NH}_{2}\right), 1.29-1.46$ (complex m, $4 \mathrm{H}, 4 \mathrm{e}, 6, \mathrm{CH}_{B}-\mathrm{H}$ ), 1.53-1.66 (complex m, 3H, H-8, 10a), 1.72-1.83 (complex m, 3H, H-5, 7, 10e), 1.91 (d, 1H, H-3), 2.00-2.05 (m, 2H, 4a, $\mathrm{H}-9 \mathrm{a}), 2.66-2.80\left(\mathrm{~m}, 2 \mathrm{H}, \mathrm{CH}_{2} \mathrm{CH}_{2} \mathrm{NH}_{2}\right.$ ), 3.17 (br s, $3 \mathrm{H}, \mathrm{NH}_{2}, \mathrm{OH}$ ), $3.45-3.46$ (d, $1 \mathrm{H}, \mathrm{H}-2) ;{ }^{13} \mathrm{C} \mathrm{NMR}\left(\mathrm{CDCl}_{3}, 100 \mathrm{MHz}\right), \delta(\mathrm{ppm}) 28.1$ (C5, 7), 30.8 (C-4), 34.5 (C-3), $35.3\left(\mathrm{CH}_{2} \mathrm{NH}_{2}\right), 35.6$ (C-9), 36.6 (C-10), 37.0 (C-1), 37.4 (C-8), 44.0 (C-6), $44.8\left(\mathrm{CH}_{2} \mathrm{CH}_{2} \mathrm{NH}_{2}\right), 75.6$ (C-2).
Anal. Calcd. for $\mathrm{C}_{12} \mathrm{H}_{21} \mathrm{NO}$ Calcd. (\%): C: $73.80, \mathrm{H}: 10.84, \mathrm{~N}: 7.17$. Found (\%): C: 73.71, H: 10.81, N: 7.31.

\subsection{N-methyl-2-(2-pyridinyl)-tricyclo[3.3.1.1]decan-2-amine (32) $[3,7]$}

To a stirred solution of $2.5 \mathrm{M} \mathrm{n}$-BuLi in hexanes $(12.2 \mathrm{ml}$, $30.5 \mathrm{mmol})$, a solution of 2-bromopyridine ( $4.81 \mathrm{~g}, 30.5 \mathrm{~mol})$ in dry ether $(30 \mathrm{ml})$ was added dropwise at $-85^{\circ} \mathrm{C}$ under argon atmosphere. The mixture was then warmed to $-42{ }^{\circ} \mathrm{C}$ and a solution of imine $31(2.0 \mathrm{~g}, 12.2 \mathrm{mmol})$ and 1-(2-methoxyphenoxy)- $\mathrm{N}, \mathrm{N}-$ dimethyl-3-phenylpropan-2-amine $(2.0 \mathrm{~g}, 13.3 \mathrm{mmol})$ in dry toluene $(25 \mathrm{ml})$ was added dropwise over $30 \mathrm{~min}$. The reaction mixture was stirred at $-42{ }^{\circ} \mathrm{C}$ for $3 \mathrm{~h}$ and allowed to reach slowly room temperature and poured into water under ice cooling. The organic layer was separated and the aqueous layer was extracted with ether and the combined organic extracts were washed several times with water, dried $\left(\mathrm{Na}_{2} \mathrm{SO}_{4}\right)$, and evaporated in vacuo to give a viscuous oil. After purification with flash column chromatography through silica gel using ether as eluent the solid base $\mathbf{3 2}$ was obtained ( $1.55 \mathrm{~g}, 53 \%) ; \mathrm{mp} 71{ }^{\circ} \mathrm{C}$ ( $n$-hexane); ${ }^{1} \mathrm{H}$ NMR $(400 \mathrm{MHz}$, $\mathrm{CDCl}_{3}$ ), $\delta$ (ppm): 1.25 (bs, $\left.1 \mathrm{H}, \mathrm{NH}\right), 1.56-1.76$ (m, 9H, H-4e, 6, 7, 8, 9e, 10), $1.82(\mathrm{~s}, 1 \mathrm{H}, \mathrm{H}-5), 1.84\left(\mathrm{~s}, 3 \mathrm{H}, \mathrm{CH}_{3}\right), 2.32(\mathrm{~d}, 2 \mathrm{H}, \mathrm{J}=11.6 \mathrm{~Hz}, \mathrm{H}-4 \mathrm{a}$, 9a), 2.52 (s, 2H, H-1, 3), $7.02(\mathrm{t}, J=7.2 \mathrm{~Hz}, 5.2 \mathrm{~Hz}, 5-\mathrm{Hpyr}), 7.25$ (d, $J=8.0 \mathrm{~Hz}, 3-\mathrm{Hpyr}$ ), 7.58 (t, $J=15.6 \mathrm{~Hz}, 8.0 \mathrm{~Hz}, 4-\mathrm{Hpyr}), 8.54$ (d, $J=4.8 \mathrm{~Hz}, 6-\mathrm{Hpyr}) ;{ }^{13} \mathrm{C}$ NMR $\left(100 \mathrm{MHz}, \mathrm{CDCl}_{3}\right), \delta(\mathrm{ppm}): 27.1$ (C-5), $27.5\left(\mathrm{CH}_{3}\right), 27.9(\mathrm{C}-7), 32.0(\mathrm{C}-1,3), 32.4(\mathrm{C}-4,9), 34.1(\mathrm{C}-8,10), 38.1$ (C-6), 63.1 (C-2), 120.8 (C-5pyr), 121.2 (C-3pyr), 135.2 (C-4pyr), 149.1 (C-6pyr), 163.9 (C-2pyr). Anal. Calcd. for $\mathrm{C}_{16} \mathrm{H}_{22} \mathrm{~N}_{2}$ Calcd. (\%): C: 79.29, H: 9.15. Found (\%): C: 79.61, H: 9.49.

\subsection{4-[3-(Dimethylamino)propylo]-4-tricyclo[4.3.1.0]decanol} (36) $[3,8]$

A solution of (3-chloropropyl)dimethylamine (8.09 g, $66.6 \mathrm{mmol})$ in dry benzene $(50 \mathrm{ml})$ was added dropwise to magnesium turnings ( $1.7 \mathrm{~g}, 0.071 \mathrm{~g}$-at)] and the mixture was stirred and heated until complete dissolution. Then a solution of protoadamantanone 25 (2.00 g, $13.3 \mathrm{mmol})$ in dry benzene $(25 \mathrm{ml})$ was added and the mixture was refluxed for $4 \mathrm{~h}$ and then was hydrolyzed under ice cooling by the addition of saturated $\mathrm{NH}_{4} \mathrm{Cl}$ solution. The aqueous phase was extracted with $\mathrm{Et}_{2} \mathrm{O}(3 \times 20 \mathrm{ml})$ and the combined organic extracts were washed with water $(3 \times 20 \mathrm{ml})$ and dried $\left(\mathrm{Na}_{2} \mathrm{SO}_{4}\right)$. The solvent was evaporated in vacuo and the residue formed was crystallized upon treatment with $n$-pentane. The solid was filtered off and washed with a cold $n$-pentane to give aminoalcohol 36 (3.06 g, 97\%) as a white solid; mp $67^{\circ} \mathrm{C}$ ( $n$-hexane) I.R. (Nujol) $v(\mathrm{OH}) 3288 \mathrm{~cm}^{-1}$. ${ }^{1} \mathrm{H}$ NMR $\left(400 \mathrm{MHz}, \mathrm{CDCl}_{3}\right), \delta(\mathrm{ppm})$ : $1.26(\mathrm{~d}, J=12.8 \mathrm{~Hz}, 1 \mathrm{H}, \mathrm{H}-9 \mathrm{e}), 1.39$ (dd, $J=13.4 \mathrm{~Hz}, 1.6 \mathrm{~Hz}, 1 \mathrm{H}, \mathrm{H}-$ 10e), 1.45 (dd, $J=11.2 \mathrm{~Hz}, 2.8 \mathrm{~Hz}, 1 \mathrm{H}, \mathrm{H}-5 \mathrm{e}$ ), 1.52-1.83 (complex m, 9H, H-4e, 5a, 7e, 9a, 10a, $\left.\mathrm{CH}_{2} \mathrm{CH}_{2} \mathrm{CH}_{2} \mathrm{~N}, \mathrm{CH}_{2} \mathrm{CH}_{2} \mathrm{CH}_{2} \mathrm{~N}\right), 1.89-1.92(\mathrm{~m}$, 2H, H-6, 7a), 1.97 (dd, $J=13.6 \mathrm{~Hz}, 2.8 \mathrm{~Hz}, 1 \mathrm{H}, \mathrm{H}-2 \mathrm{a}), 2.06-2.12$ (m, $3 \mathrm{H}, \mathrm{H}-1,3,8), 2.19\left(\mathrm{~s}, 6 \mathrm{H}, 2 \mathrm{xCH}_{3}\right), 2.28(\mathrm{t}, J=11.6 \mathrm{~Hz}, 5.6 \mathrm{~Hz}, 2 \mathrm{H}$, $\mathrm{CH}_{2} \mathrm{CH}_{2} \mathrm{CH}_{2} \mathrm{~N}$ ), 6.30 (bs, $\left.1 \mathrm{H}, \mathrm{OH}\right) ;{ }^{13} \mathrm{C} \mathrm{NMR}\left(100 \mathrm{MHz}, \mathrm{CDCl}_{3}\right.$ ), $\delta$ (ppm): $22.2\left(\mathrm{CH}_{2} \mathrm{CH}_{2} \mathrm{CH}_{2} \mathrm{~N}\right), 29.9(\mathrm{C}-6), 32.6(\mathrm{C}-9), 33.5(\mathrm{C}-1), 34.2$ (C-2), 35.5 (C-8), 40.2 (C-10), $41.4\left(\mathrm{CH}_{2} \mathrm{CH}_{2} \mathrm{CH}_{2} \mathrm{~N}\right), 42.6(\mathrm{C}-7), 43.0$ (C-5), $45.0\left(2 \mathrm{xCH}_{3}\right), 46.3(\mathrm{C}-3), 60.1\left(\mathrm{CH}_{2} \mathrm{CH}_{2} \mathrm{CH}_{2} \mathrm{~N}\right), 71.5$ (C-4). Anal. Calcd. for $\mathrm{C}_{15} \mathrm{H}_{27}$ NO Calcd. (\%): C: $75.90, \mathrm{H}: 11.46, \mathrm{~N}$ : 5.90. Found (\%): C: 76.11, H: 11.19, N: 6.27 .

\subsection{1-[3-(dimethylamino)propyl]-tricyclo[3.3.1.1]decan-2-ol (37) $[3,7]$}

A solution of aminoalcohol 36 ( $2.30 \mathrm{~g}$, $9.7 \mathrm{mmol})$ and $\mathrm{H}_{2} \mathrm{SO}_{4} 15 \%$ $(10 \mathrm{ml})$ in dioxane $(25 \mathrm{ml})$ was heated in a boiling steam bath for 
$2 \mathrm{~h}$. After removal in vacuo of diaxane, the residue was alkalized with an aq solution of $\mathrm{NaOH} 10 \%$, extracted with $\mathrm{Et}_{2} \mathrm{O}$ and the combined organic extracts were dried $\left(\mathrm{Na}_{2} \mathrm{CO}_{3}\right)$. The solvent was evaporated in vacuo to give $\mathbf{3 7}$ as a viscous oil (2.15 g, 93\%), which was converted to its hydrochloride salt. $\mathrm{Mp}_{\mathrm{HCl}} 206^{\circ} \mathrm{C}\left(\mathrm{EtOH}^{\mathrm{E}} \mathrm{Et}_{2} \mathrm{O}\right)$. I.R.(Nujol) $v(\mathrm{OH}) 3190 \mathrm{~cm}^{-1}$. ${ }^{1} \mathrm{H}$ NMR $\left(400 \mathrm{MHz}, \mathrm{CDCl}_{3}\right), \delta(\mathrm{ppm})$ : $1.03\left(\mathrm{t}, J=13.2 \mathrm{~Hz}, 4.6 \mathrm{~Hz}, 2 \mathrm{H}, \mathrm{CH}_{2} \mathrm{CH}_{2} \mathrm{CH}_{2} \mathrm{~N}\right.$ ), 1.11 (bs, $\left.1 \mathrm{H}, \mathrm{H}-9 \mathrm{e}\right), 1.14$ (bs, 1H, H-10e), 1.28-1.94 (complex m, 13H, H-3, 4, 5, 6, 7, 8 9a, 10a, $\mathrm{CH}_{2} \mathrm{CH}_{2} \mathrm{CH}_{2} \mathrm{~N}$ ), $2.16\left(\mathrm{~s}, 6 \mathrm{H}, 2 \mathrm{xCH}_{3}\right), 2.27(\mathrm{t}, J=11.6 \mathrm{~Hz}, 5.6 \mathrm{~Hz}, 2 \mathrm{H}$, $\left.\mathrm{CH}_{2} \mathrm{CH}_{2} \mathrm{CH}_{2} \mathrm{~N}\right), 3.51(\mathrm{~s}, 1 \mathrm{H}, \mathrm{H}-2), 3.82(\mathrm{bs}, 1 \mathrm{H}, \mathrm{OH}) ;{ }^{13} \mathrm{C} \mathrm{NMR}$ (100 MHz, $\left.\mathrm{CDCl}_{3}\right), \delta(\mathrm{ppm}): 19.7\left(\mathrm{CH}_{2} \mathrm{CH}_{2} \mathrm{CH}_{2} \mathrm{~N}\right), 28.1(\mathrm{C}-5), 28.2(\mathrm{C}-$ 7), 30.9 (C-4), 34.7 (C-3), 36.5 (C-10), 36.9 (C-1), 37.0 $\left(\mathrm{CH}_{2} \mathrm{CH}_{2} \mathrm{CH}_{2} \mathrm{~N}\right), 37.4$ (C-6), 37.9 (C-9), $40.4(\mathrm{C}-8), 45.3\left(2 \mathrm{xCH}_{3}\right), 60.6$ $\left(\mathrm{CH}_{2} \mathrm{CH}_{2} \mathrm{CH}_{2} \mathrm{~N}\right), 75.2$ (C-2). Anal. Calcd. for $\mathrm{C}_{15} \mathrm{H}_{27} \mathrm{NO}$ Calcd. (\%): C: 75.90, H: 11.46, N: 5.90. Found (\%): C: 76.25, H: 11.30, N: 6.07.

\subsection{1-[3-(dimethylamino)propyl]-tricyclo[3.3.1.1]decan-2-one (38) $[3,7]$}

To a solution of aminoalcoholol $37(1.34 \mathrm{~g}, 5.6 \mathrm{mmol})$ in acetone $(25 \mathrm{ml})$ was added, during a $0.5 \mathrm{~h}$ period, Jones reagent $(20.0 \mathrm{ml}$, $1 \mathrm{mM}$ ) at $15^{\circ} \mathrm{C}$. After stirring for $24 \mathrm{~h}$ at ambient temperature, isopropanol $(3 \mathrm{ml})$ was added and stirring was continued for an additional $1 \mathrm{~h}$. The reaction mixture was filtered off and the filtrate was evaporated in vacuo. The residue was alkalified with $\mathrm{Na}_{2} \mathrm{CO}_{3}$ and then was extracted with $\mathrm{Et}_{2} \mathrm{O}(3 \times 20 \mathrm{ml})$. The combined organic extracts were washed with water $(2 \times 10 \mathrm{ml})$, dried $\left(\mathrm{Na}_{2} \mathrm{CO}_{3}\right)$, concentrated in vacuo to afford aminoketone $38(1.14 \mathrm{~g}$, 87\%) as a viscous oil; I.R. (Nujol): $v(\mathrm{C}=\mathrm{O}) 1710=\mathrm{cm}^{-1} \cdot{ }^{1} \mathrm{H}$ NMR (400 MHz, $\left.\mathrm{CDCl}_{3}\right), \delta(\mathrm{ppm})$ 1.30-1.35 (m, 2H, $\left.\mathrm{CH}_{2} \mathrm{CH}_{2} \mathrm{CH}_{2} \mathrm{~N}\right)$, 1.37-1.46 (m, $2 \mathrm{H}, \mathrm{CH}_{2} \mathrm{CH}_{2} \mathrm{CH}_{2} \mathrm{~N}$ ), 1.56-2.08 (complex m, 12H, H-4, 5, 6, 7, 8, 9, 10), $2.19\left(\mathrm{~s}, 6 \mathrm{H}, 2 \mathrm{xCH}_{3}\right), 2.23(\mathrm{t}, J=14.4 \mathrm{~Hz}, 6.8 \mathrm{~Hz}, 2 \mathrm{H}$, $\mathrm{CH}_{2} \mathrm{CH}_{2} \mathrm{CH}_{2} \mathrm{~N}$ ), 2.51 (bs, $\left.1 \mathrm{H}, \mathrm{H}-3\right) ;{ }^{13} \mathrm{C} \mathrm{NMR}\left(50 \mathrm{MHz}, \mathrm{CDCl}_{3}\right), \delta(\mathrm{ppm})$ $21.5\left(-\mathrm{CH}_{2} \mathrm{CH}_{2} \mathrm{~N}\right), 28.1(\mathrm{C}-5,7), 30.7\left(-\mathrm{CH}_{2} \mathrm{CH}_{2} \mathrm{CH}_{2} \mathrm{~N}\right), 39.3(\mathrm{C}-4,9)$, $44.1(\mathrm{C}-8,10), 45.5\left(2 \mathrm{xCH}_{3}\right), 47.1$ (C-3), 49.2 (C-1), 60.5 $\left(\mathrm{CH}_{2} \mathrm{CH}_{2} \mathrm{CH}_{2} \mathrm{~N}\right), 218.2(\mathrm{C}=\mathrm{O})$. Anal. Calcd. for $\mathrm{C}_{15} \mathrm{H}_{25} \mathrm{NO}$ : C: $76.55, \mathrm{H}$ : 10.71. Found: C: $76.86, \mathrm{H}: 10.95$.

\subsection{1-[3-(dimethylamino)propyl]-tricyclo[3.3.1.1]decan-2-one oxime (39) [3,7]}

A mixture of ketone $38(0.70 \mathrm{~g}, 2.9 \mathrm{mmol}), \mathrm{NH}_{2} \mathrm{OH} \cdot \mathrm{HCl}(0.41 \mathrm{~g}$, $6.0 \mathrm{mmol})$ and $\mathrm{CH}_{3} \mathrm{COONa} .3 \mathrm{H}_{2} \mathrm{O}(1.36 \mathrm{~g}, 10.0 \mathrm{mmol})$ and ethanol $90 \%(10 \mathrm{ml})$ was refluxed for $3 \mathrm{~h}$. The ethanol was removed in vacuo and the residue was alkalized with $\mathrm{Na}_{2} \mathrm{CO}_{3}$, extracted with ether, dried $\left(\mathrm{Na}_{2} \mathrm{CO}_{3}\right)$ and concentrated under reduced pressure to give 39 as a white low melting solid $\left(0.77 \mathrm{~g}\right.$, quantitative yield); $\mathrm{mp} 64{ }^{\circ} \mathrm{C}$ ( $n$-hexane). IR. (Nujol): $v 1648 \mathrm{~cm}^{-1}(\mathrm{C}=\mathrm{N})$.

\subsection{2-Amino-N,N-dimethyl-tricyclo[3.3.1.1]decane-1- propanamine (40) [3,7]}

A solution of oxime 39 (550 $\mathrm{mg}, 2.2 \mathrm{mmol})$ in dry EtOH was hydrogenated over Raney-Ni catalyst for $5 \mathrm{~h}$, at $65^{\circ} \mathrm{C}$, and under pressure ( $55 \mathrm{psi}$ ). The catalyst was filtered off and the solvent was evaporated under vacuum to afford a viscous oil (amine 40) (570 mg, 95\% yield), which was converted to its hydrochloride salt; $\mathrm{Mp}_{\mathrm{HCl}}>250{ }^{\circ} \mathrm{C}(\mathrm{EtOH}) ;{ }^{1} \mathrm{H}$ NMR $\left(400 \mathrm{MHz}, \mathrm{CDCl}_{3}\right), \delta$ (ppm) 0.93 (bd, 1H, 9e), 1.16-1.85 (complex m, 18H, H-3, 4a, 5, 6, 7, 8, 9, 10, $\left.\mathrm{CH}_{2} \mathrm{CH}_{2} \mathrm{CH}_{2} \mathrm{~N}, \mathrm{CH}_{2} \mathrm{CH}_{2} \mathrm{CH}_{2} \mathrm{~N}, \mathrm{NH}_{2}\right), 2.18\left(\mathrm{~s}, 6 \mathrm{H}, 2 \mathrm{CCH}_{3}\right), 2.19(\mathrm{t}$, $J=14.2 \mathrm{~Hz}, 6.5 \mathrm{~Hz}, 2 \mathrm{H}, \mathrm{CH}_{2} \mathrm{CH}_{2} \mathrm{CH}_{2} \mathrm{~N}$ ), 2.67 (bs, $\left.1 \mathrm{H}, \mathrm{H}-2\right) ;{ }^{13} \mathrm{C} \mathrm{NMR}$ (50 MHz, $\left.\mathrm{CDCl}_{3}\right), \delta(\mathrm{ppm}) 20.2\left(-\mathrm{CH}_{2} \mathrm{CH}_{2} \mathrm{~N}\right), 28.2(\mathrm{C}-5), 28.4(\mathrm{C}-7)$, $30.6\left(-\mathrm{CH}_{2} \mathrm{CH}_{2} \mathrm{CH}_{2} \mathrm{~N}\right), 35.6(\mathrm{C}-3), 35.7$ (C-1), 36.8 (C-4), 37.2 (C-10), 37.4 (C-6), 37.5 (C-9), 41.1 (C-8), $45.5\left(2 \mathrm{xCH}_{3}\right), 57.3(\mathrm{C}-2), 60.6$
$\left(\mathrm{CH}_{2} \mathrm{CH}_{2} \mathrm{CH}_{2} \mathrm{~N}\right)$. Anal. Calcd. for $\mathrm{C}_{15} \mathrm{H}_{29} \mathrm{ClN}_{2}$ : C: 66.03, H: 10.71 . Found: C: 66.39, H: 11.09 .

\subsection{4. (2E)-1-phenyl tricyclo[3.3.1.1]decan-2-one oxime (45) [3,7]}

A mixture of the ketone 44 [9d] (900 mg, $3.9 \mathrm{mmol}$ ), hydroxylamine hydrochloride ( $490 \mathrm{mg}, 7.0 \mathrm{mmol}$ ), and sodium acetate trihydrate $(1.90 \mathrm{~g}, 14.0 \mathrm{mmol})$ in $\mathrm{EtOH}(25 \mathrm{ml})$ and $\mathrm{H}_{2} \mathrm{O}(2.5 \mathrm{ml})$ was refluxed for $3 \mathrm{~h}$. After evaporation under reduced pressure of $1 / 3$ of the volume of the solvents, $\mathrm{H}_{2} \mathrm{O}$ was added to the residue and the solid material formed was filtered, washed with $\mathrm{H}_{2} \mathrm{O}$ and dried to give after recrystallization $\left(\mathrm{EtOH} / \mathrm{H}_{2} \mathrm{O}\right)$ the desired oxime $\mathbf{4 5}$ as a white crystalline solid (923 $\mathrm{mg}, 98 \%$ ); $\mathrm{mp} 250{ }^{\circ} \mathrm{C}$ (dec.). IR. (Nujol): $v 1662 \mathrm{~cm}^{-1}(\mathrm{C}=\mathrm{N})$.

\subsection{1-Phenyl-tricyclo[3.3.1.1]decan-2-amine (46) [3,7]}

1-Phenyladamantan-2-one oxime (819 $\mathrm{mg} 3.4 \mathrm{mmol})$ in absolute $\mathrm{EtOH}(25 \mathrm{ml})$ under $\mathrm{H}_{2}$ (55 psi) in the presence of Raney Ni was heated at $90^{\circ} \mathrm{C}$ for $8 \mathrm{~h}$. The resulting suspension was filtered through Celite, and the filtrate was concentrated in vacuo to give $0.63 \mathrm{~g}$ of a viscous liquid product, which was treated with an $\mathrm{HCl}$ saturated ethanolic solution. The solvent was evaporated, and water was added to the resulting residue, which was chilled to $0^{\circ} \mathrm{C}$. The precipitate formed was filtered, washed with water, and dried to give the hydrochloride salt of the title amine $\mathbf{4 6}$. Yield $81 \%$. $\mathrm{Mp}>255{ }^{\circ} \mathrm{C}$ (hydrochloride salt, EtOH/Et $\left.2 \mathrm{O}\right) .{ }^{1} \mathrm{H}$ NMR $(400 \mathrm{MHz}$, $\left.\mathrm{CDCl}_{3}\right): \delta=1.19(\mathrm{~d}, 1 \mathrm{H}, J=12.0 \mathrm{~Hz}, \mathrm{H}-9 \mathrm{e}), 1.31-2.03(\mathrm{~m}, 14 \mathrm{H}, \mathrm{H}-3,3$, 4, 5, 6, 7, 8, 9a, 10, NH $), 2.61$ (s, 1H, H-2), 7.00-7.27 (m, 5H, Haromatic); ${ }^{13} \mathrm{C}$ NMR (100 MHz, $\left.\mathrm{CDCl}_{3}\right), \delta(\mathrm{ppm}) 28.3(\mathrm{C}-5,7), 30.5$ (C-9), 35.9 (C-4), 36.1 (C-3), 37.2 (C-6), 37.6 (C-1, 8), 41.1 (C-10), 59.4 (C-2), $126.1\left(\mathrm{C}_{\mathrm{arom}}-4\right), 128.6\left(\mathrm{C}_{\mathrm{arom}}-2,6\right), 131.6\left(\mathrm{C}_{\mathrm{arom}}-3,5\right), 148.4$ $\left(\mathrm{C}_{\text {arom }}-1\right)$. Anal. Calcd. for $\mathrm{C}_{16} \mathrm{H}_{22} \mathrm{ClN}$ : C: 72.85 , H: 8.41 . Found: $\mathrm{C}$ : 72.52, H: 8.09.

\subsection{Tricyclo[4.3.1.0]decan-4-one oxime (47) [3,8]}

A mixture of protoadamantanone $25(700 \mathrm{mg}, 4.7 \mathrm{mmol})$, hydroxylamine hydrochloride (590 $\mathrm{mg}, 8.4 \mathrm{mmol}$ ), and sodium acetate trihydrate $(2.28 \mathrm{~g}, 16.8 \mathrm{mmol})$ in EtOH $(25 \mathrm{ml})$ and $\mathrm{H}_{2} \mathrm{O}$ $(5 \mathrm{ml})$ was refluxed for $3 \mathrm{~h}$. After evaporation under reduced pressure of $1 / 3$ of the volume of the solvents, $\mathrm{H}_{2} \mathrm{O}$ was added to the residue and the solid material formed was filtered, washed with $\mathrm{H}_{2} \mathrm{O}$ and dried to give after recrystallization $\left(\mathrm{Et}_{2} \mathrm{O} / \mathrm{PE}\right)$ the desired oxime 47 as a white crystalline solid (543 mg, 70\%); mp $128^{\circ} \mathrm{C}$ (dec.). IR. (Nujol): $v 3209 \mathrm{~cm}^{-1}(\mathrm{OH}), 1666 \mathrm{~cm}^{-1}(\mathrm{C}=\mathrm{N})$.

\subsection{4-Tricyclo[4.3.1.0]decanamime (48) [3,8]}

Oxime 47 (330 mg $2.0 \mathrm{mmol}$ ) in absolute EtOH (15 ml) under $\mathrm{H}_{2}$ (55 psi) in the presence of Raney Ni was heated at $90^{\circ} \mathrm{C}$ for $8 \mathrm{~h}$. The resulting suspension was filtered through Celite, and the filtrate was concentrated in vacuo to give $0.63 \mathrm{~g}$ of a viscous liquid product, which was treated with an $\mathrm{HCl}$ saturated ethanolic solution. The solvent was evaporated, and water was added to the resulting residue, which was chilled to $0^{\circ} \mathrm{C}$. The precipitate formed was filtered, washed with water, and dried to give the hydrochloride salt of the title amine 48. Yield $70 \% . \mathrm{Mp}>250^{\circ} \mathrm{C}$ (hydrochloride salt, EtOH/Et $\left.{ }_{2} \mathrm{O}\right)$. I.R.(Nujol) $v 3280 \mathrm{~cm}^{-1}\left(\mathrm{NH}_{2}\right) ;{ }^{1} \mathrm{H}$ NMR $(400 \mathrm{MHz}$, $\mathrm{CDCl}_{3}$ ) endo/exo, 1/1,, $\delta$ (ppm) 0.98-2.20 (complex $\mathrm{m}, 14 \mathrm{H}, 1,2,3,5$, $\left.6,7,8,9,10-\mathrm{H}, \mathrm{NH}_{2}\right), 2.34(\mathrm{t}, 1 \mathrm{H}, 4-\mathrm{H}) ;{ }^{13} \mathrm{C} \mathrm{NMR}\left(\mathrm{CDCl}_{3}, 100 \mathrm{MHz}\right)$, $\delta(\mathrm{ppm}) 28.8 / 28.9$ (6-C), 31.1 (7-C), 31.8/31.9 (2-C), 34.6/34.7 (8-C), 35.1/35.2 (1-C), 39.7/39.9 (5-C), 41.3/41.6 (10-C), 42.6 (9-C), 43.3/ 43.5 (3-C), 49.5/49.9 (4-C). Anal. Calcd. for $\mathrm{C}_{10} \mathrm{H}_{18} \mathrm{ClN}$ : C: $63.99, \mathrm{H}$ : 9.67. Found: C: $63.75, \mathrm{H}: 9.35$. 


\subsection{T. brucei culturing and drug test}

Bloodstream form $T$. brucei (strain 427 ) were cultured at $37^{\circ} \mathrm{C}$ in modified Iscove's medium [33]. Trypanocidal activity was assessed by growing parasites in $4 \mathrm{ml}$ cultures for $48 \mathrm{~h}$ in the presence of a range of drug concentrations, from 0.1 to $25 \mu \mathrm{M}$, and determining the levels which inhibited growth by $50 \%\left(\mathrm{IC}_{50}\right)$ and $90 \%\left(\mathrm{IC}_{90}\right)$. In the case of untreated cultures, cell densities increased from $0.25 \times 10^{5}$ to $1 \times 10^{6}$ over this period. Cell densities at each drug concentration were determined using a hemocytometer and drug sensitivity was expressed as a percentage of growth of control cells.

\section{Acknowledgments}

Dr. Zoidis would like to thank the State Scholarship Foundation of Greece and the University of Athens (ELKE Account) for financial support. L. Naesens acknowledges the financial support from the International Consortium for Anti-Virals (ICAV); the Flemish Fonds voor Wetenschappelijk Onderzoek (FWO No. 9.0188.07) and the Geconcerteerde Onderzoeksacties (GOA/10/014); and the technical assistance from Leentje Persoons and Frieda De Meyer. J. Kelly acknowledges support from the Wellcome Trust (Ref. 5632).

\section{References}

[1] (a) J.K. Taubenberger, A.H. Reid, R.M. Lourens, R. Wang, G. Jin, T.G. Fanning, Nature 437 (2005) 889-893;

(b) R.J. Webby, R.G. Webster, Science 302 (2003) 1519-1522.

[2] (a) C.J. Russell, R.G. Webster, Cell 123 (2005) 368-371;

(b) R.G. Webster, R.J. Webby, E. Hoffmann, J. Rodenberg, M. Kumar, H.-J. Chu, P. Seiler, S. Krauss, T. Songserm, Virology 351 (2006) 303-311;

(c) A.N. Abdel-Ghafar, T. Chotpitayasunondh, Z. Gao, F.G. Hayden, D.H. Nguyen, M.D. de Jong, A. Naghdaliyev, J.S. Peiris, N. Shindo, S. Soeroso, T.M. Uyeki, N. Eng. J. Med. 358 (2008) 261-273.

[3] World Health Organization (WHO) (2009).

[4] (a) R.B. Belshe, N. Engl. J. Med. 353 (2005) 2209-2211;

(b) E. De Clercq, J. Neyts, Trends Pharmacol. Sci. 28 (2007) 280-285.

[5] (a) T.M. Tumpey, A. Garcva-Sastre, A. Mikulasova, J.K. Taubenberger, D.E. Swayne, P. Palese, C.F. Basler, Proc. Natl. Acad. Sci. U.S.A. 99 (2002) 13849-13854; (b) N.A. Ilyushina, N.V. Bovin, R.G. Webster, E.A. Govorkova, Antiviral Res. 70 (2006) 121-131.

[6] (a) A.J. Hay, A.J. Wolstenholme, J.J. Skehel, M.H. Smith, EMBO J. 4 (1985) 3021-3024;

(b) A.J. Hay, Semin. Virol. 3 (1992) 21-30.

[7] L.H. Pinto, L.J. Holsinger, R.A. Lamb, Cell 69 (1992) 517-528.

[8] In Burger's Medicinal Chemistry, fifth ed.; Wolff, M.E., John Wiley \& Sons: New York; vol. 4, pp 590-591.

[9] (a) N. Kolocouris, G.B. Foscolos, A. Kolocouris, P. Marakos, N. Pouli, G. Fytas, S. Ikeda, E. De Clercq, J. Med. Chem. 37 (1994) 2896-2902;

(b) N. Kolocouris, A. Kolocouris, G.B. Foscolos, G. Fytas, J. Neyts, E. Padalko, J. Balzarini, R. Snoeck, A. Graciela, E. De Clercq, J. Med. Chem. 39 (1996) 3307-3318;

(c) G. Zoidis, N. Kolocouris, G.B. Foscolos, A. Kolocouris, G. Fytas, P. Karayannis, E. Padalko, J. Neyts, E. De Clercq, Antiviral Chem. Chemother. 14 (2003) 153-164; (d) I. Papanastasiou, A. Tsotinis, N. Kolocouris, S.R. Prathalingam, J.M. Kelly, J. Med. Chem. 51 (2008) 1496-1500;

(e) N. Kolocouris, G. Zoidis, G.B. Foscolos, G. Fytas, R.S. Prathalingham, J.M. Kelly, L. Naesens, E. De Clercq, Bioorg. Med. Chem. Lett. 17 (2007) 4358-4362;

(f) G. Zoidis, A. Tsotinis, N. Kolocouris, J.M. Kelly, R.S. Prathalingham, L. Naesens, E. De Clercq, Org. Biomol. Chem. 6 (2008) 3177-3185;

(g) G. Zoidis, N. Kolocouris, L. Naesens, E. De Clercq, Bioorg. Med. Chem. 17 (2009)
1534-1541;

(h) G. Zoidis, D. Benaki, V. Myrianthopoulos, L. Naesens, E. De Clercq, E. Mikros, N. Kolocouris, Tetrahedron Lett. 50 (2009) 2671-2675;

(i) E. De Clercq, Nat. Rev. Drug Disc. 5 (2006) 1015-1025;

(j) A. Kolocouris, P. Spearpoint, S.R. Martin, A.J. Hay, M. López-Querol, F.X. Sureda, E. Padalko, J. Neyts, E. De Clercq, Bioorg. Med. Chem. Lett. 18 (2008) 6156-6160.

[10] Recently an X-ray structure of M2TM and M2TM-amantadine complex was published from the DeGrado's group: (a) A.L. Stouffer, R. Acharya, D. Salom, A.S. Levine, L. Di Costanzo, C.S. Soto, V. Tereshko, V. Nanda, S. Stayrook W. DeGrado, Nature 451 (2008) 596-599 The first work on the amantadine location inside the M2 protein pore was a neutron diffraction study:;

(b) K.C. Duff, P.J. Gilchrist, A.M. Saxena, J.P. Bradshaw, Virology 202 (1994) 287-293 Elegant solid-state NMR studies on this system have been carried out by N. Cross lab:

(c) J. Hu, T. Asbury, S. Achuthan, C. Li, R. Bertram, J.R. Quine, R. Fu, T.A. Cross, Biophys. J. 92 (2007) 4335-4343 For molecular dynamics studies of the M2TM-amantadine or rimantadine complex see:;

(d) M.S.P. Sansom, I.D. Kerr, Protein Eng. 6 (1993) 65-74;

(e) M. Yi, T.A. Cross, H.-X. Zhou, J. Phys. Chem. B 112 (2008) 7977-7979;

(f) P. Intharathep, C. Laohpongspaisan, T. Rungrotmongkol, A. Loisruangsin, M. Malaisree, P. Decha, O. Aruksakunwong, K. Chuenpennit, N. Kaiyawet, P. Sompornpisut, S. Pianwanit, S. Hannongbua, J. Mol. Graph. Model. 27 (2009) 921-929.

[11] (a) C. Wang, K. Takeuchi, L.W. Pinto, R.A. Lamb, J. Virol. 67 (1993) 5585-5594; (b) I.V. Chizhmakov, F.M. Geraghty, D.C. Ogden, A. Hayhurst, M. Antoniou, A.J. Hay, J. Physiol. 494 (1996) 329-336.

[12] (a) L. Pinto, R.A. Lamb, J. Biol. Chem. 281 (2006) 8997-9000;

(b) L. Pinto, R.A. Lamb, FEBS Lett. 560 (2004) 1-2;

(c) W.B. Fischer, M.S.P. Sansom, Biochim. Biophys. Acta 1561 (2002) 27-45;

(d) See the articles in, FEBS Lett. 552 (2003) 1.

[13] S. Grambas, A.J. Hay, Virology 190 (1992) 11-18.

[14] World Health Report, 2004, Statistical Annex Table 2.

[15] P.G.E. Kennedy, J. Clin. Invest. 113 (2004) 496-504.

[16] S.L. Croft, M.P. Barrett, J.A. Urbina, Trends Parasitol. 21 (2005) 508-512.

[17] W.E. Gutteridge, Brit. Med. Bull. 41 (1985) 162-168.

[18] F. Doua, F.B. Yapo, Acta Trop. 54 (1993) 163-168.

[19] P.G.E. Kennedy, Int. J. Parasitol. 36 (2006) 505-512.

[20] J.M. Kelly, M.A. Miles, A.C. Skinner, Antimicrob. Agents Chemother. 43 (1999) 985-987.

[21] J.M. Kelly, G. Quack, M.A. Miles, Antimicrob. Agents Chemother. 45 (2001) 1360-1366.

[22] J.L.M.A. Schlatmann, J.G. Korsloot, J. Schut, Tetrahedron 26 (1970) 949-954.

[23] M.Yu. Skomorokhov, M.V. Leonova, A.K. Shiryaev, Yu. N. Klimochkin, Russ. J. Org. Chem. 39 (2003) 1360-1361.

[24] (a) Z. Majersky, Z. Hamesrak, Org. Synth. 50 (1988) 958-962; (b) N. Kolocouris, G. Zoidis, C. Fytas, Synlett 7 (2007) 1063-1066.

[25] D. Setaki, D. Tataridis, G. Stamatiou, A. Kolocouris, G.B. Foscolos, G. Fytas, N. Kolocouris, E. Padalko, J. Neyts, E. De Clercq, Bioorg. Chem. 34 (2006) 248-273.

[26] C.D. Jones, M. Kaselj, R.N. Salvatore, W.J. le Noble, J. Org. Chem. 63 (1998) 2758-2760.

[27] (a) Y.M. Shafran, V.A. Bakulev, V.S. Mokrushin, Russ. Chem. Rev. 58 (1989) 148-162;

(b) N.A. Hassan, E. Bayer, J.C. Jochims, J. Chem. Soc., Perkin Trans. 1 (1998) 3747-3757.

[28] D. Tataridis, G. Fytas, A. Kolocouris, C. Fytas, N. Kolocouris, G.B. Foscolos, E. Padalko, J. Neyts, E. De Clercq, Bioorg. Med. Chem. Lett. 17 (2007) 692-696.

[29] (a) E. Vanderlinden, F. Goktas, Z. Cesur, M. Froeyen, M.L. Reed, C.J. Russell, N. Cesur, L. Naesens, J. Virol. (2010 Feb 24) (Epub ahead of print);

(b) L. Naesens, E. Vanderlinden, E. Roth, J. Jeko, G. Andrei, R. Snoeck C. Pannecouque, E. Illyés, G. Batta, P. Herczegh, F. Sztaricskai, Antiviral Res. 82 (2009) 89-94.

[30] S.R. Wilkinson, J.M. Kelly, Expert Rev. Mol. Med. 11 (2009) e31.

[31] S.R. Wilkinson, M.C. Taylor, D. Horn, J.M. Kelly, I. Cheeseman, Proc. Natl. Acad Sci. USA 105 (2008) 5022-5027.

[32] O. Yun, G. Priotto, J. Tong, L. Flevaud, F. Chappuis, PLoS Negl. Trop. Dis. 4 (2010) e720.

[33] S.R. Wilkinson, R. Prathalingam, M.C. Taylor, A. Ahmed, D. Horn, J.M. Kelly, Free Radic. Biol. Med. 40 (2006) 198-209. 